\title{
Article
}

\section{The Modeling and Forecasting of Carabid Beetle Distribution in Northwestern China}

\author{
Xueqin Liu ${ }^{1}$, Hui Wang ${ }^{2}$, Dahan He ${ }^{1}$, Xinpu Wang ${ }^{1, * \mathbb{D}}$ and Ming Bai ${ }^{1,3, *}$ \\ 1 School of Agriculture, Ningxia University, Yinchuan 750021, China; liuxueqin@nxu.edu.cn (X.L.); \\ hedahan@163.com (D.H.) \\ 2 Institute of Green Manure, Yan'an Academy of Agricultural Sciences, Yan'an 716000, China; \\ wangbin1986221@126.com \\ 3 Key Laboratory of Zoological Systematics and Evolution, Institute of Zoology, Chinese Academy of Sciences, \\ Beijing 100101, China \\ * Correspondence: wangxinpu@nxu.edu.cn (X.W.); baim@ioz.ac.cn (M.B.)
}

check for updates

Citation: Liu, X.; Wang, H.; He, D.; Wang, X.; Bai, M. The Modeling and Forecasting of Carabid Beetle Distribution in Northwestern China. Insects 2021, 12, 168. https:// doi.org/10.3390/insects12020168

Received: 10 January 2021

Accepted: 11 February 2021

Published: 16 February 2021

Publisher's Note: MDPI stays neutral with regard to jurisdictional claims in published maps and institutional affiliations.

Copyright: (c) 2021 by the authors. Licensee MDPI, Basel, Switzerland. This article is an open access article distributed under the terms and conditions of the Creative Commons Attribution (CC BY) license (https:// creativecommons.org/licenses/by/ $4.0 /)$.
Simple Summary: The relationship between species and environment are an important basis for the study of biodiversity. Most researchers have found the distribution of indicator insects such as carabid beetle at the local community scale; however, a few studies on the distribution of indicator insects in grassland in China. Here, we used Generalized Additive Models (GAM) to predict temperate steppe of northwestern China carabid beetle species richness distribution, and to determine the possible underlying causal factors. Predicted values of beetle richness ranged from 3 to 12 . The diversity hotspots are located in the southwest, south and southeast of the study area which have moist environment, the carabid beetle is mainly influenced by temperature and precipitation. The results underline the importance of management and conservation strategies for grassland and also provides evidence for assessing beetle diversity in temperature steppe.

Abstract: Beetles are key insect species in global biodiversity and play a significant role in steppe ecosystems. In the temperate steppe of China, the increasing degeneration of the grasslands threatens beetle species and their habitat. Using Generalized Additive Models (GAMs), we aimed to predict and map beetle richness patterns within the temperate steppe of Ningxia (China). We tested 19 environmental predictors including climate, topography, soil moisture and space as well as vegetation. Climatic variables (temperature, precipitation, soil temperature) consistently appeared among the most important predictors for beetle groups modeled. GAM generated predictive cartography for the study area. Our models explained a significant percentage of the variation in carabid beetle richness $(79.8 \%)$, carabid beetle richness distribution seems to be mainly influenced by temperature and precipitation. The results have important implications for management and conservation strategies and also provides evidence for assessing and making predictions of beetle diversity across the steppe.

Keywords: conservation; indicators; species distribution modeling; species richness; generalized additive models; steppe; China

\section{Introduction}

The relationship between species and environment has always been a central topic in ecological research, the spatial distribution of species is closely related to environment [1]. Climate and human activity as a main threat to global biodiversity is increasing, the Global Assessment Report on Biodiversity and Ecosystem Services of IPBES [2] recorded that one million animal and plant species are facing extinction at present, destroying ecosystem functions and services. Therefore, efficient management tools are urgently needed to protect biodiversity and maintain global ecosystem functioning and services [3-5]. 
One management tool is to improve the predictive ability of biodiversity distribution models, such as niche models, species distribution and habitat suitability [6,7]. Studies have shown that a diverse ecosystem characteristic have been predicted from the main environmental drivers, including species distribution, richness, biodiversity value and soil characteristics and also proved models was very valuable to biodiversity research and mostly useful for policy makers [8,9]. Ideally, planning biodiversity conservation should integrate as many taxonomic groups as possible, including indicator insect groups such as the carabid beetles. Carabid beetles are an essential component of global biodiversity and play a vital role in global ecosystems (e.g., indicator, predators) $[10,11]$. Carabids are commonly used to studies grassland management, as their ecology is well-known [12,13]. Beetles are sensitive to environmental change and perceived good for agriculture, so ecologists and taxonomists have turned to carabid beetles to test ecological research questions, thus beetle currently faced numerous threats $[14,15]$. The main threats come from the land use and grassland degradation, which leads to the loss and degradation of beetle habitats [16-18], inducing changes in beetle community composition [19-21]. The relationships between the environment and beetle communities are complex phenomena. Generalized Additive Models (GAM) can best describe these linear or nonlinear relationships between beetle and environment by using nonparametric smoothing terms [22]. Hence, based on the advantage of GAM for accommodating nonlinear relationships between variables, GAM is expected to efficiently model the relationship between environmental variables and beetle diversity and provide reliable results.

Specifically, in China, grassland vegetation, which accounts for $80 \%$ of the steppe, is degrading rapidly due to climate change and human activities that are changing productive steppe into barren land and desert [23]. The degradation will have a huge impact on steppe biodiversity and there is an urgent need to study the ecology of groups that may serve as an indicator insect. Modelling procedures can be useful tools to provide robust and accurate estimates of current and future distributions, abundance, and the population dynamics of species, and these can be directly applied to conservation and management practices [24].

Carabid beetles (Coleoptera: Carabidae) represent an abundant and diverse insect group [25,26] and account for an important fraction of total diversity [27-29]. The vital contributions of this taxonomic group to ecosystem management have been largely recorded, for example, they are used as an index of habitat restoration, land use, degree of urbanization and an indicator of shrub erosion in the steppe $[13,30,31]$. In addition, these species can prey on a large number of pest insects [32]. Despite beetles having proven ecological benefits and service in grassland ecosystems, their distribution patterns have been poorly recorded $[33,34]$ which currently is endangering the maintenance of their ecological roles. Therefore, it is essential to integrate information about beetle diversity and distribution into grassland sustainable development strategies to improve or at least conserve their biodiversity and ecosystem services in steppe regions.

However, field investigations are challenging because of remoteness, inaccessibility of many steppe areas and shortage of staff. Species Distribution models (SDMs) provide a cost-effective tool to overcome these limitations and remotely assess biodiversity over large areas at regular intervals over time [35,36]. SDMs have been widely used to assess distribution and diversity patterns of different organisms [37-39]. Increasing numbers of studies use SDMs to assess, model, predict or map species' distribution and analyze biodiversity [40-42].

Here, we used Generalized Additive Models (GAM) to predict and map beetle richness patterns [43]. In this study, we contribute to model the species richness in unmeasured area to promote grassland management and develop a conservation policy strategy for governments and also to determine the main driving factor of beetle's distribution. Our overall aim is to the conserve beetle biodiversity and maintain their ecosystem services in the grassland regions which form the main ecology in northwestern China. 


\section{Materials and Methods}

\subsection{Study Area}

This study was undertaken in two regions of Ningxia Hui Autonomous Region which represent a temperate steppe ecosystem in northwestern China and comprised between $36^{\circ}$ north $(\mathrm{N})$ and $38^{\circ} \mathrm{N}$ and between $105^{\circ}$ east $(\mathrm{E})$ and $108^{\circ} \mathrm{E}$.

(1) Yanchi region, characterized by a cold, semi-arid continental monsoon-influenced climate, with a mean annual temperature of $5.7^{\circ} \mathrm{C}$ and mean annual precipitation of $200 \mathrm{~mm}$ [44]. The soil was of sierozem and the representative vegetation is Agropyron mongolicum, Artemisia desertorum, Lespedez adavurica and Artemisia blepharolepis.

(2) Guanyuan region, characterized by a semi-arid continental monsoon-influenced climate, with a mean annual temperature of $7^{\circ} \mathrm{C}$ and mean annual precipitation of $400 \mathrm{~mm}$ [44]. The soil was of black thorn and brown and the representative vegetation is Stipa bungeana, Artemisia frigida, Potentilla acaulis and Stipa grandis.

\subsection{Beetle Data}

The beetle data used in this study was from the steppe of northwestern of China which was sampled in 2017, 2018 and 2019; we selected 124 sampling sites and at each sampling site placed at random five pitfall traps (separated by at least five meters from each other), all sampling site were separated by at least $150 \mathrm{~m}$ in order to avoid possible autocorrelation. Samples were taken from May to September every year, which allowed us to obtain a good representation of carabid richness. We accounted for number of beetle once a month and take the average of five times for analysis. We divided each study area into $10 \times 10 \mathrm{~km}^{2}$ grid squares in order to discriminate adequately-surveyed grid squares, the value of each $100 \mathrm{~km}^{2}$ grid, well surveyed were identified and recorded of all species observed (Figure 1). Five pitfall traps (400 mL capacity, $7.5 \mathrm{~cm}$ diameter, filled with 40-60 mL of a 2:1:1:20 vinegar, sugar, alcohol and water solution and covered with a suspended opaque plastic roof) were placed at each site and collected three days later. Trapped beetles were stored in $75 \%$ ethanol and transported to the laboratory for identification to species level with the aid of a taxonomist expert in carabid beetles (Prof. H. Liang, see Acknowledgments). Analyses were conducted using the pooled data from the average values every year.

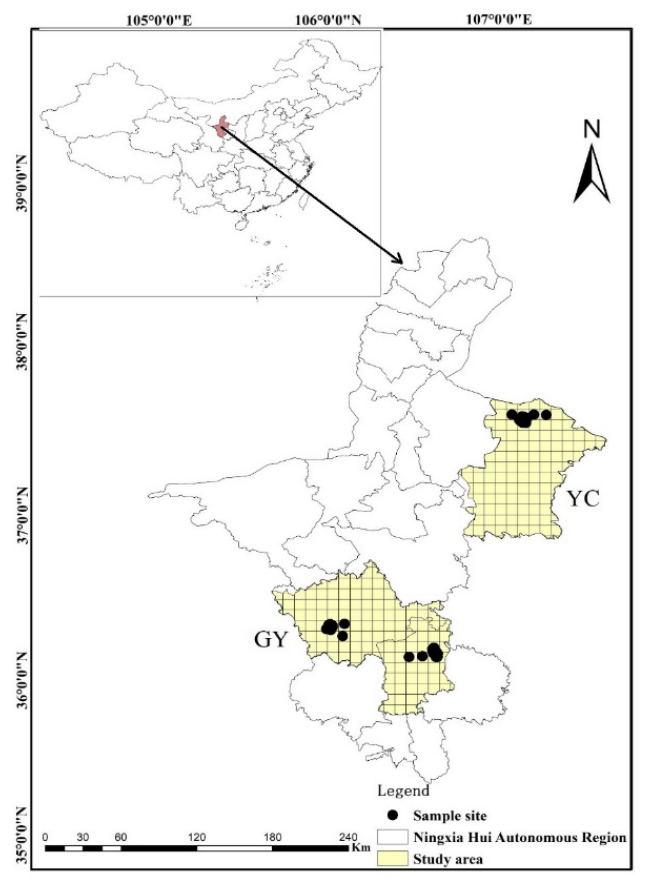

Figure 1. Study areas and sampling site $(n=124)$ in the Ningxia Hui Autonomous Region, northwestern China (YC, Yanchi region; GY, Guyuan region). 


\subsection{Environmental, Spatial and Climatic Data}

At each sampling site, we selected a $1 \times 1 \mathrm{~m}$ quadrat frame (the habitat around each site is very homogeneous) and measured plant dry biomass (PB), cover (PC, \%), density (PD), height (PHe), plant richness (PSD), litter dry mass (SL, $\left.\mathrm{g} / \mathrm{m}^{2}\right)$, soil moisture (SM, \%), bulk density (SBD), and soil temperature (ST), soil organic matter (C), total phosphorus $(\mathrm{P})$, total nitrogen $(\mathrm{N}), \mathrm{pH}$ value $(\mathrm{pH})$. Above of vegetation and soil were measured once a month. The soil moisture and temperature (underground $10 \mathrm{~cm}$ ) were measured by a portable soil water potential temperature tester (TRS-II, China). The climate data including the maximum and minimum monthly mean temperature $(\mathrm{T}, \mathrm{t})$, the annual mean temperature (TM), and annual precipitation $(p)$ were extracted climatic dataset (www.worldclim.org, accessed on 1 December 2020). The spatial data (longitude (Lon) and latitude (Lat)) and the geographical data (altitude (Alt)) were measured by GPS (G128BD, China). The information of variables saw Table A1.

\subsection{Data Processing and Statistical Analyses}

Species activity density was calculated as the number of individuals per square meter; Margalef index was calculated using the formula: $(S-1) / \ln ^{N}, S$ is the number of species, where $n$ is the number of collected individuals per square, species richness was expressed as the number of beetle species in a given grid cell. All analyses were performed in R v.4.0.3.

\subsection{Model Building}

A total of 19 potential predictors were preselected. First, the method of variance inflation factor was used to select the most important environmental predictors for each response variable and the largest variable was deleted in turn, that is, the collinear environmental factors were deleted, until all variables were less than 10 from the 'car' package in $\mathrm{R}$ (v.4.0.3). This package (vif function) can help us to identify and keep important relevant predictors in our models. Second, the predictor factors were further refined by using the Pearson correlation coefficient to identify highly correlated variables $(|r|)>0.7)$ and avoid the inclusion of redundant variables in our models. The goodness-factor for the competing functions was measured by an F-ratio with a $5 \%$ significance level and the non-significant factors were removed (Table A2). Third, a backward stepwise procedure was used to enter the variables into the model [45]. The step model was used to detect the lowest AIC value, and the optimal environmental factor was automatically selected. When "none" is at the top, it means the end of model selection. The number of beetle richness as dependent variable in order to remove the non-significant spatial terms. The significant spatial terms $(p<0.05)$ were retained.

The sampling is stratified random sampling. The soil and environmental factors of the unsampled grids were interpolated based on the statistical relationship among the surrounding measured site in each year. To compare different result for GAMs and GLM, an independent dataset was used. The data from 2017 to 2018 for training set and data from 2019 as test set were randomly chosen to evaluate offset between predicted values of the model and the original values. For model validation, we used a correlation coefficient between predictive and real species richness values. The higher the value of the correlation coefficient, the higher the predictive power of the model.

\subsection{Model Fitting and Selection}

Species distributions were modelled with generalized linear model (GLM) and Generalized Additive Models (GAM) in order to seek the best model. GLMs are defined by the response distribution and a link function. The structure is as follows:

$$
g\left(\mu_{i}\right)=x_{i}^{T} \beta
$$

where $g$ is the differentiable and monotonic link function, $\mu_{i}=E\left(Y_{i}\right), x_{i}$ is the explanatory variable for the ith response variable, $\beta$ is a vector of the parameters. The log-transformation 
has been found to be fit for many situations and data sources, despite its great generality, the GLM has serious limitations. Generally, AIC is usually used criterion for model selection when GLMs/GAMs are used to estimate species richness [46].

GAM is an extension of the Generalized Linear Modelling (GLM; [47]) which uses a link function to establish a relationship between the mean of the response variable and a 'smoothed' function of the explanatory variable $[48,49]$. GAMs can model highly non-linear and non-monotonic relationships between the response and the set of explanatory variables. GAM has been widely applied in ecological research, as shown by the growing number of published papers incorporating modern regression [50-53]. GAM implemented in the mgcv package in $\mathrm{R}$ (4.0.3). The most optimum model was selected with the lowest Akaike Information Criterion (AIC) and residual deviance [54]. The general form is as follows:

$$
g(\mu(Y))=\beta_{0}+f_{1}\left(x_{1}\right)+\cdots+f_{m}\left(x_{m}\right)
$$

where $g($.$) is the connection function; \mu(Y)$ is the expected value of the response variable $Y ; \beta_{0}$ is a constant; and $f_{m}($.$) is a smooth function of the explanatory variable x_{m}$.

Poisson distribution for species richness was used. To avoid data overfitting, the basic dimension was defined as $\mathrm{k}=4$. In order to improve model performance, the values of the parameters of the GAM algorithm were optimized independently for each model, selecting those that minimized the AIC; this step has been considered as providing an estimate of model reliability. For model assessment, the evidence ratio, AIC and minimized generalized cross validation (GCV) score were applied. The smaller the values of GCV, the better the models fit [55].

\section{Results}

\subsection{Population Size}

The mean number of the carabid beetle (number of beetles in each grid cell) was $39.88 \pm$ 79.4 individuals $/ \mathrm{km}^{2}$, the mean number of beetle species was $8.92 \pm 1.11$ individuals $/ \mathrm{km}^{2}$. On the other hand, species activity density was 0.897 individuals $/ \mathrm{m}^{2}$ and the Margalef index was 8.54 .

\subsection{Fitted Model}

Compare to GLM, results for comparing performances are shown in Table 1. According the AIC criterion results showed that GAMs has a lower score compared to GLM (AIC$\mathrm{GLM}=609.54$, AIC-GAM $=598.04)$. In addition, $\mathrm{R}^{2}(0.774), p$-value $(<0.001)$ and correlation coefficient (0.923) also indicated that GAM has a high quality for model performance, GAMs fitted the observed data as much as possible by enabling the smooth effects of the continuous predictors as well as the spatial structure of the data (Table 1).

Table 1. Summary of stepwise of the GAM and GLM of variables.

\begin{tabular}{|c|c|c|c|c|c|c|c|}
\hline \multirow{2}{*}{$\begin{array}{c}\text { Model } \\
\text { Variables }\end{array}$} & \multicolumn{4}{|c|}{ GLM } & \multicolumn{3}{|c|}{ GAM } \\
\hline & $\begin{array}{l}\text { Deviance } \\
\text { Residual }\end{array}$ & $\begin{array}{c}\text { Df. Residual } \\
\text { Deviance }\end{array}$ & F & $p$ & df & $\mathbf{F}$ & $p$ \\
\hline Latitude & 11.53 & 148.67 & 5.872 & 0.635 & 1 & 1.436 & 0.23360 \\
\hline $\begin{array}{l}\text { Maximum mean } \\
\text { temperature }\end{array}$ & 3.35 & 144.17 & 6.725 & $0.005^{* * *}$ & 3.734 & 5.336 & $0.00060^{* * *}$ \\
\hline $\begin{array}{l}\text { Mean annual } \\
\text { precipitation }\end{array}$ & 11.2 & 137.47 & 0.094 & 0.925 & 6.071 & 9.013 & $<0.05^{*}$ \\
\hline Plant density & 9.67 & 138.05 & -2.406 & $0.016^{*}$ & 5.861 & 0.773 & 0.49420 \\
\hline Soil bulk density & 6.45 & 117.9 & 0.465 & 0.465 & 6.428 & 4.333 & 0.03988 \\
\hline Soil temperature & 29.42 & 137.87 & 1.967 & 0.049 * & 1 & 3.285 & $0.00499 * * *$ \\
\hline PH value & 18.43 & 106.27 & 5.660 & $<0.001^{* * *}$ & 1 & 1.486 & 0.22563 \\
\hline AIC & & 609.54 & & & & 598.04 & \\
\hline $\mathrm{R}^{2}$ & & 0.682 & & & & 0.774 & \\
\hline$p$-value & & $<0.001$ & & & & $<0.001$ & \\
\hline correlation coefficient & & 0.907 & & & & 0.923 & \\
\hline
\end{tabular}


The stepwise algorithm parameters used to develop the models, as well as F value and $\mathrm{P}$ estimates are listed in Table 1. Seven environmental variables: maximum mean temperature, mean annual precipitation, latitude, longitude, plant density, soil bulk density, soil temperature, and $\mathrm{PH}$ value were statistically significant after the collinearity analysis of all environmental factors (Table A3). Among the seven environmental variables, the maximum mean temperature $(\mathrm{F}=5.336, p<0.00046)$, mean annual precipitation $(\mathrm{F}=9.031$, $p<0.05)$ and soil temperature $(\mathrm{F}=5.336, p<0.001)$ had statistically significant effects on species, whereas soil and climatic variables consistently appeared among the most important predictors for the richness of beetle groups modeled (Table 2). General trends seem to be very well identified by the GAM. The GAM parameters used to develop the models, as well as adjust the fit factor (R2), generalized cross validation (GCV) and deviance explained are listed in Table 2. By comparing the different explanation variable of function of GAM results, selection of model variance explained the largest volume, minimum generalized cross validation, $\mathrm{F}$ test $(p)$ model of the highest accuracy rate value as the optimal model, in general, when the rate of $\mathrm{F}$ test value $(p<0.05)$, indicating that explain the response variables affect significantly, if adjust the fitting coefficient $\left(\mathrm{R}^{2}\right)$ is greater than 0.5 , that model has good stability and effectively explains the response variables and explains the relationship between the variables. Among the seven predictor variables, the full model was the best adjusted explaining $79.8 \%$ of the variation, the GCV was 0.062 and the adjust the fitting coefficient $\left(\mathrm{R}^{2}\right)$ was 0.774 , our model showed a good predictive performance for beetle richness and the best model was log (species richness) $=\mathrm{s}(\mathrm{T})+$ $\mathrm{s}(p)+\mathrm{s}(\mathrm{ST})$. Plots of the relationship of predicted richness distribution and environment variables are shown in Figure 2; the distribution of beetle richness mainly depends on the maximum mean temperature, mean annual precipitation and soil temperature. The relationship between maximum mean temperatures, mean annual precipitation and spatial distribution of beetle were complex, but it was positively correlated with soil temperature change (Figure 2).

Table 2. The result of GAM of variables to build the models for the beetle richness. Variable codes as in Table A1.

\begin{tabular}{cccccc}
\hline $\begin{array}{c}\text { Environmental } \\
\text { Factor }\end{array}$ & df & $\mathbf{F}$ & $\begin{array}{c}\text { Adjust the } \\
\text { Fit Factor } \\
\left.\mathbf{( R}^{2}\right)\end{array}$ & $\begin{array}{c}\text { Generalized Cross } \\
\text { Validation (GCV) }\end{array}$ & $\begin{array}{c}\text { Deviance } \\
\text { Explained } \\
\mathbf{( \% )}\end{array}$ \\
\hline $\mathrm{p}$ & 8.991 & $<0.001$ & 0.727 & 0.073 & $74.7 \%$ \\
$\mathrm{~T}$ & 8.999 & $<0.001$ & 0.694 & 0.08 & $71.6 \%$ \\
$\mathrm{ST}$ & 8.626 & $<0.001$ & 0.455 & 0.1449 & $49 \%$ \\
$\mathrm{p}+\mathrm{T}$ & 8.856 & $<0.001$ & 0.729 & 0.0737 & $75.2 \%$ \\
$\mathrm{p}+\mathrm{ST}$ & 8.991 & $<0.001$ & 0.753 & 0.066 & $77.3 \%$ \\
$\mathrm{~T}+\mathrm{ST}$ & 8.981 & $<0.001$ & 0.758 & 0.068 & $78.5 \%$ \\
$\mathrm{p}+\mathrm{T}+\mathrm{ST}$ & 8.689 & $<0.001$ & 0.774 & 0.062 & $79.8 \%$ \\
\hline
\end{tabular}

\subsection{Predictive Mapping}

The results from the predictive mapping of the beetle richness at the spatial level are shown in Figure 3. Predicted values of beetle richness ranged from 3 to 12. Three diversity hotspots are located in the southwest, south and southeast of the study area. The statistics of the coefficient of variation showed that, overall, predictions from individual GAMs of beetle richness at the spatial level were stable. 

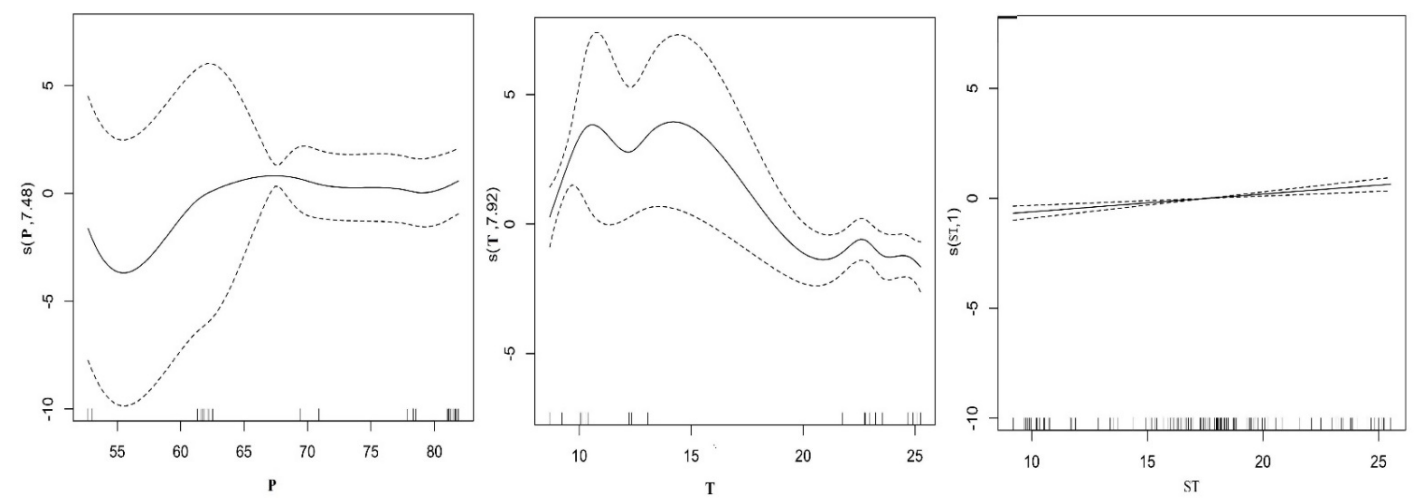

Figure 2. Response curves of carabid beetle and factors kept in the GAM analysis. The vertical axes are expressed in logits, and the value (s) represents the smoothing fitting value of explanatory variable of beetle species, the ordinate in parentheses is the estimated degrees of freedom. Solid curves are the function estimates, and dashed curves delimit the $95 \%$ confidence intervals for each function.



Figure 3. Predictive beetle richness for the study area. Red colors correspond to areas predicted to be species rich, while yellow and green colors correspond to areas predicted to harbor intermediate and low levels of richness.

\section{Discussion}

SDMs are important ecological tools for conservation planning and management [56]. The present study demonstrates the efficacy of SDMs to assess the species richness of beetle in grassland. GAM analysis suggested that the three most important factors, which showed the largest effect of the beetle richness, were mean maximum temperature, annual precipitation and soil temperature. The soil temperature changed with the temperature, the result supported the factors determining beetle life cycles include variation in temperature and rainfall [57]. Our model explained a significant fraction (0.77) of the variation in beetle richness. Our study also provides a potential methodology for conservation of the species groups.

The model of distribution of beetle richness helps understanding the relationships between beetles and their environment, and thus is useful for protection and management purposes. GAM used smooth functions to deal with nonlinear relationships between the response variable and explanatory variables, increasing evidence that GAM is likely to be 
more suitable to estimate the distribution of species richness $[43,58]$. GAMs showed good performance for species richness estimation in the present study $(79.8 \%)$, and robustly explain the relationship between the variables and species richness. Our study demonstrated that climatic factors, especially temperature and precipitation are the important environmental factors generating richness patterns of the beetle group. Both temperature and precipitation show a curvilinear relationship with species richness and had a significant effect on beetle species, this result agrees with those obtained in earlier studies of carabid beetles [19]. Although, the suitable maximum annual temperature value is around $20^{\circ} \mathrm{C}$, the effect may be reflecting the effect of temperatures of the warmest months which can limit the activity of beetles according to their tolerance to desiccation. Because most carabids are active on the ground, their body temperature depends directly on the ambient temperature and it is known that species activity can be stimulated by temperature [59]. The importance of precipitation can be explained by the free ranging life style of immature larval stages. The amount of precipitation enhances the aboveground vegetation biomass [60], and vegetation provides food and shelter (from the environment and predators) for the herbivorous species. However, precipitation hinders the survival of some of these species when it exceeds the threshold value. The soil temperature has a significant correlation with carabid beetle richness. Because some species lay eggs in burrows, and others overwinter as larvae or as adults in the soil, the soil temperature can stimulate or hinder species activity. We suggest that lower observed beetle richness may be due to the higher temperature, precipitation, and correlated soil temperature in those areas.

Carabid beetles also respond to microhabitat conditions. Carabids perceived microhabitat variation and selected niches accordingly [61], increasing evidence that management of microhabitats is a key tool for conserving ecosystem function. The Carabid beetle fauna in the steppe ecosystem in Ningxia Hui Autonomous Region has been recorded over ten years, but the beetle information only shows where the entomologist sampled and the composition of beetle $[62,63]$. In this study, we have shown that with a reasonable sampling distribution, predictive variables for species richness can be derived efficiently from GIS-based data for areas in which species inventories have not yet been conducted, and a reliable forecasted map of species richness may be obtained. The forecasted map can be used to plan and carry out new, targeted studies and regional surveys thus saving on the resources needed for large-scale surveys. It is very expensive and may be impractical to sample all poorly surveyed areas. The forecasted map also can provide an opportunity to manage these habitats and conserved carabid taxa.

Carabid beetles live in moist habitats and are excellent model species on research of ecological and conservation theory [64-66]. The 3rd International Carabidologists' Meeting emphasized that it is needed to concern on the effects of habitat loss and fragmentation on dynamics of beetle population if wise decisions are to be made regarding conservation and land-use [67]. These beetles readily respond to disturbances and management. Our results show that it is quick and inexpensive to employ forecasting models using simple environmental variables and adequately sampled areas to produce an estimate of the spatial distribution of species richness and obtain reasonable biogeographic patterns. Relating biological data to environmental variables without adding geographic position as a model predictor sometimes overestimates the actual species richness $[68,69]$. Our results demonstrate that elaborating predictive models using simple environmental variables is quicker and less expensive when based on the concept of adequately sampled areas. Consequently, our model for the species richness of carabid beetle distribution provides a good substitute for information that could not be provided otherwise in the coming years. This information will focus sampling efforts, and also inform management and conservation strategies.

\section{Conclusions}

Our models explained a significant fraction of the variation in beetle richness (79.8\%), and predictive mapping of carabid beetle richness at the spatial level helped us to identify 
important variables determining the richness of beetle species. For the carabid group of beetles, species richness variation was influenced primarily by the climatic factors of maximum temperature and precipitation. If the survival of carabid species is constrained by temperature and precipitation (few species can tolerate high temperature and precipitation), we argue that species richness variation in the steppe of northwestern China is due mainly to the failure of many species to go beyond determined temperature and precipitation range limits. Thus, the regions richest in species are those with a temperature and precipitation compatible with the maintenance of populations.

Author Contributions: Conceptualization, all authors; methodology, H.W., L.X, D.H.; software, X.L.; validation, M.B., X.W. and X.L.; formal analysis, X.L.; investigation, H.W.; resources, X.W.; data curation, X.L.; writing—original draft preparation, X.L.; writing—review and editing, X.L.; visualization, M.B.; supervision, X.W.; project administration, X.L.; funding acquisition, X.W. All authors have read and agreed to the published version of the manuscript.

Funding: This research was funded by the National Natural Science Foundation of China, (grant number 31660630, 31961143002) and the First-class discipline of Prataculture Science of Ningxia University (grant number NXYLXK2017A01).

Institutional Review Board Statement: This study was not involving humans or animals.

Data Availability Statement: The data presented in this study are available on request from the corresponding author. The data are not publicly available due to uncompleted subject.

Acknowledgments: We thank Hongbin Liang (Institute of Zoology, Chinese Academy of Sciences) for identifying specimens. We are grateful to Rentao Liu (Laboratory for Restoration and Reconstruction of Degraded Ecosystem in Northwestern China) for the geospatial modeling analysis for species richness and prediction, and to Fang Ouyang (Institute of Zoology, Chinese Academy of Sciences) for advice and data analysis by GAM.

Conflicts of Interest: The authors declare no conflict of interest.

\section{Appendix A}

Table A1. Species and individuals of Carabidae in different region (2017-2019).

\begin{tabular}{|c|c|c|c|c|c|c|c|c|c|c|c|c|}
\hline \multirow[b]{2}{*}{ Genera } & \multirow[b]{2}{*}{ Species } & \multirow[b]{2}{*}{ Abbreviation } & \multicolumn{3}{|c|}{2017} & \multicolumn{3}{|c|}{2018} & \multicolumn{3}{|c|}{2019} & \multirow[b]{2}{*}{ Total } \\
\hline & & & $\begin{array}{l}\text { Yanchi } \\
\text { Region }\end{array}$ & $\begin{array}{l}\text { Guyuan } \\
\text { Region }\end{array}$ & Total & $\begin{array}{l}\text { Yanchi } \\
\text { Region }\end{array}$ & $\begin{array}{c}\text { Guyuan } \\
\text { Region }\end{array}$ & Total & $\begin{array}{l}\text { Yanchi } \\
\text { Region }\end{array}$ & $\begin{array}{c}\text { Guyuan } \\
\text { Region }\end{array}$ & Total & \\
\hline \multirow{4}{*}{ Amara } & Amara helva & AmarHel & 9 & 0 & 9 & 40 & 0 & 40 & 4 & 0 & 4 & 53 \\
\hline & Amara dux & AmarDux & 6 & 61 & 67 & 4 & 13 & 17 & 7 & 8 & 15 & 99 \\
\hline & Amara sp & Amarsp & 0 & 15 & 15 & 13 & 3 & 16 & 0 & 0 & 0 & 31 \\
\hline & Amara harpaloides & AmarHar & 7 & 4 & 11 & 1 & 4 & 5 & 5 & 7 & 12 & 28 \\
\hline Broscus & Broscus kozlovi & BrosKoz & 0 & 8 & 8 & 0 & 3 & 3 & 4 & 0 & 4 & 15 \\
\hline \multirow{7}{*}{ Carabus } & \multirow{7}{*}{$\begin{array}{c}\text { Carabus ladimirskyi } \\
\text { Carabus glyptoterus } \\
\text { Carabus } \\
\text { assesculptus } \\
\text { Carabus } \\
\text { culptipennis } \\
\text { Carabu } \\
\text { anchocephalus } \\
\text { Carabus modestulus } \\
\text { Carabus gigoloides }\end{array}$} & CaraVla & 3 & 2036 & 2039 & 0 & 316 & 316 & 4 & 466 & 470 & 2825 \\
\hline & & CaraGly & 252 & 634 & 886 & 85 & 92 & 177 & 55 & 75 & 130 & 1193 \\
\hline & & CaraCra & 0 & 339 & 339 & 0 & 198 & 198 & 0 & 88 & 88 & 625 \\
\hline & & CaraScu & 0 & 404 & 404 & 0 & 73 & 73 & 1 & 61 & 62 & 539 \\
\hline & & CaraAnc & 0 & 85 & 85 & 0 & 21 & 21 & 0 & 0 & 0 & 106 \\
\hline & & CaraMod & 0 & 84 & 84 & 0 & 88 & 88 & 0 & 192 & 192 & 364 \\
\hline & & CaraGig & 0 & 267 & 267 & 0 & 329 & 329 & 0 & 7 & 7 & 603 \\
\hline \multirow{3}{*}{ Calosoma } & Calosoma lugens & CaloLug & 0 & 11 & 11 & 0 & 0 & 0 & 2 & 1 & 3 & 14 \\
\hline & Calosoma anthrax & CaloAnt & 0 & 41 & 41 & 0 & 7 & 7 & 0 & 11 & 11 & $\begin{array}{l}14 \\
59\end{array}$ \\
\hline & Calosoma chinense & CaloChi & 1 & 2 & 3 & 0 & 0 & 0 & 0 & 0 & 0 & 3 \\
\hline \multirow{2}{*}{ Cymindis } & Cymindis binotata & CymiBin & 19 & 0 & 19 & 8 & 1 & 9 & 9 & 3 & 12 & 3 \\
\hline & Cymindis daimio & CymiDai & 0 & 0 & 0 & 0 & 2 & 2 & 1 & 0 & 1 & 10 \\
\hline Corsyra & Corsyra fusula & CorsFus & 3 & 0 & 3 & 4 & 0 & 4 & 3 & 0 & 3 & 3 \\
\hline Dolichus & Dolichus halensis & DoliHal & 0 & 3 & 3 & 0 & 0 & 0 & 0 & 0 & 0 & 15 \\
\hline Harpalus & Harpalus lumbaris & HarpLum & 11 & 0 & 11 & 2 & 1 & 3 & 1 & 0 & 1 & 1329 \\
\hline \multirow[b]{2}{*}{ Poecillus } & Poecillus gebleri & PoecGeb & 0 & 1145 & 1145 & 0 & 158 & 158 & 5 & 21 & 26 & 687 \\
\hline & Poecillus fortipes & PoecFor & 0 & 552 & 552 & 0 & 53 & 53 & 3 & 79 & 82 & 411 \\
\hline \multirow{2}{*}{ Pseudotaphoxenus } & $\begin{array}{l}\text { Pseudotaphoxenus } \\
\text { rugipennis }\end{array}$ & PesuRug & 3 & 307 & 310 & 0 & 62 & 62 & 3 & 36 & 39 & 123 \\
\hline & $\begin{array}{c}\text { Pseudotaphoxenus } \\
\text { mongolicus }\end{array}$ & PesuMon & 23 & 54 & 77 & 13 & 1 & 14 & 25 & 7 & 32 & 466 \\
\hline Reflexisphodrus & $\begin{array}{l}\text { Reflexisphodrus } \\
\text { reflexipennis }\end{array}$ & ReflRef & 0 & 368 & 368 & 0 & 78 & 78 & 0 & 20 & 20 & 133 \\
\hline \multirow[t]{2}{*}{ Zabrus } & Zabrus potanini & ZabrPot & 1 & 115 & 116 & 0 & 8 & 8 & 4 & 5 & 9 & 30 \\
\hline & Total & & 338 & 6535 & 6873 & 170 & 1511 & 1681 & 136 & 1087 & 1223 & 9767 \\
\hline
\end{tabular}


Table A2. Summary of variables data collected in the study area.

\begin{tabular}{|c|c|c|c|c|c|}
\hline Variables & Code & Unit & Maximum Value & Minimum Value & Remark \\
\hline \multicolumn{6}{|l|}{ Spatial data: } \\
\hline Latitude & LAT & $\circ$ & 38.03 & 36.2 & Converted to WGS 1984 \\
\hline Longitude & LON & $\circ$ & 107.08 & 105.6 & Converted to WGS 1984 \\
\hline \multicolumn{6}{|l|}{ Geographical data: } \\
\hline Altitude range & Alt & $\mathrm{km}$ & 2804 & 1411 & GPS \\
\hline \multicolumn{6}{|l|}{ Climatic data: } \\
\hline $\begin{array}{l}\text { Annual mean } \\
\text { temperature }\end{array}$ & $\mathrm{TM}$ & ${ }^{\circ} \mathrm{C}$ & 17.08 & 11.3 & $\begin{array}{c}\text { www.worldclim.org (accessed on } \\
1 \text { December 2020) }\end{array}$ \\
\hline $\begin{array}{l}\text { Maximum mean } \\
\text { temperature }\end{array}$ & $\mathrm{T}$ & ${ }^{\circ} \mathrm{C}$ & 25.24 & 17.08 & $\begin{array}{c}\text { www.worldclim.org (accessed on } \\
1 \text { December 2020) }\end{array}$ \\
\hline $\begin{array}{l}\text { Minimum mean } \\
\text { temperature }\end{array}$ & $\mathrm{t}$ & ${ }^{\circ} \mathrm{C}$ & 24.99 & 12.23 & $\begin{array}{c}\text { www.worldclim.org (accessed on } \\
1 \text { December 2020) }\end{array}$ \\
\hline $\begin{array}{l}\text { Mean annual } \\
\text { precipitation }\end{array}$ & $\mathrm{pp}$ & $\mathrm{mm}$ & 81.9 & 52.6 & $\begin{array}{c}\text { www.worldclim.org (accessed on } \\
1 \text { December 2020) }\end{array}$ \\
\hline \multicolumn{6}{|l|}{ Vegetation data: } \\
\hline Plant biomass & PB & $\mathrm{g} / \mathrm{m}^{2}$ & 143.79 & 17.08 & At sample site surface $(1 \times 1 \mathrm{~m})$ \\
\hline Plant height & PHe & $\mathrm{cm}$ & 71 & 11.4 & At sample site surface $(1 \times 1 \mathrm{~m})$ \\
\hline Plant density & PD & individuals $/ \mathrm{m}^{2}$ & 125.8 & 25.31 & At sample site surface $(1 \times 1 \mathrm{~m})$ \\
\hline Plant coverage & PC & $\%$ & 87.75 & 21.13 & At sample site surface $(1 \times 1 \mathrm{~m})$ \\
\hline Plant richness & PR & individuals & 8.6 & 4.3 & At sample site surface $(1 \times 1 \mathrm{~m})$ \\
\hline Aboveground litter & Lit & $\mathrm{g}$ & 189.68 & 21.76 & At sample site surface $(1 \times 1 \mathrm{~m})$ \\
\hline \multicolumn{6}{|l|}{ Soil data: } \\
\hline Soil moisture & SM & $\%$ & 31.67 & 2.6 & underground $10 \mathrm{~cm}$ \\
\hline Soil bulk density & SBD & $\mathrm{g} / \mathrm{cm}^{3}$ & 1.45 & 1.23 & underground $10 \mathrm{~cm}$ \\
\hline Soil temperature & ST & ${ }^{\circ} \mathrm{C}$ & 25.5 & 9.2 & underground $10 \mathrm{~cm}$ \\
\hline Soil organic matter & $\mathrm{C}$ & $\mathrm{g} / \mathrm{kg}$ & 40.82 & 0.17 & At sample site, random sample \\
\hline Total phosphorus & $p$ & $\mathrm{~g} / \mathrm{kg}$ & 35.01 & 0 & At sample site, random sample \\
\hline Total nitrogen & $\mathrm{N}$ & $\mathrm{g} / \mathrm{kg}$ & 5.62 & 0.005 & At sample site, random sample \\
\hline PH value & $\mathrm{PH}$ & - & 8.9 & 7.7 & At sample site, random sample \\
\hline
\end{tabular}

Table A3. The species richness of beetles and environmental factors estimated by variance inflation factor (VIF).

\begin{tabular}{|c|c|c|c|c|}
\hline Variables & Code & F & $p$ & sig \\
\hline Full model & & -5.405 & $<0.0001$ & $* * *$ \\
\hline Latitude & LAT & 5.084 & 0.00884 & $* *$ \\
\hline Longitude & LON & 2.198 & 0.02995 & \\
\hline Altitude range & Alt & 1.149 & 0.21610 & - \\
\hline \multicolumn{5}{|l|}{ Climatic data: } \\
\hline Annual mean temperature & $\mathrm{TM}$ & -0.577 & 0.56492 & - \\
\hline Maximum mean temperature & $\mathrm{T}$ & 6.106 & $<0.001$ & $* * *$ \\
\hline Minimum mean temperature & $\mathrm{t}$ & -0.967 & 0.33581 & - \\
\hline Mean annual precipitation & $\mathrm{p}$ & 2.565 & 0.01163 & * \\
\hline Plant biomass & PB & -1.111 & 0.26935 & - \\
\hline Plant height & $\mathrm{PHe}$ & -0.150 & 0.88118 & - \\
\hline Plant density & PD & -4.449 & 0.00118 & $* *$ \\
\hline Plant coverage & PC & 0.338 & 0.73574 & - \\
\hline Plant richness & PR & 0.902 & 0.36897 & - \\
\hline Aboveground litter & Lit & 0.636 & 0.52639 & - \\
\hline Soil moisture & SM & 0.850 & 0.39747 & - \\
\hline Soil bulk density & SBD & 2.840 & 0.00534 & $* *$ \\
\hline Soil temperature & ST & 6.163 & $<0.001$ & $* * *$ \\
\hline Soil organic matter & C & 1.567 & 0.12008 & - \\
\hline Total phosphorus & $\mathrm{P}$ & 0.997 & 0.32098 & - \\
\hline Total nitrogen & $\mathrm{N}$ & 0.741 & 0.46016 & - \\
\hline $\mathrm{PH}$ value & $\mathrm{PH}$ & 4.963 & $<0.001$ & $* * *$ \\
\hline
\end{tabular}




\section{References}

1. Guisan, A.; Zimmermann, N.E. Predictive habitat distribution models in ecology. Ecol. Model. 2000, 135, 147-186. [CrossRef]

2. Bongaarts, J.; Settele, J.; Díaz, S.; Ngo, H.T. Global Assessment Report on Biodiversity and Ecosystem Services; Intergovernmental Science-Policy Platform on Biodiversity and Ecosystem Services: Bonn, Germany, 2019.

3. Cardinale, B.; Emmett Duffy, J.; Gonzalez, A.; Hooper, D.; Perrings, C.; Venail, P.; Narwani, A.; Mace, G.; Tilman, D.A.; Wardle, D.E. Biodiversity loss and its impact on humanity. Nature 2012, 486, 59-67. [CrossRef]

4. Isbell, F.; Calcagno, V.; Hector, A.; Connolly, J.; Harpole, W.S.; Reich, P.B.; Scherer-Lorenzen, M.; Schmid, B.; Tilman, D.; Ruijven, J.V.; et al. High plant diversity is needed to maintain ecosystem services. Nature 2011, 477, 199-202. [CrossRef]

5. Van Strien, A.J.; Van Swaay, C.A.M.; Willy, T.F.H.; Van Strien-Van Liempt, W.T.; Poot, M.J.M.; WallisDeVries, M.F. Over a century of data reveal more than $80 \%$ decline in butterflies in the Netherlands. Biol. Conserv. 2019, 234, 116-122. [CrossRef]

6. Raffini, F.; Bertorelle, G.; Biello, R.; D’Urso, G.; Russo, D.; Bosso, L. Supplementary Materials—From Nucleotides to Satellite Imagery: Approaches to Identify and Manage the Invasive Pathogen Xylella fastidiosa and Its Insect Vectors in Europe. Sustainability 2020, 12, 4508. [CrossRef]

7. Vila-Viosa, C.M.; Arenas-Castro, S.; Marcos, B.; Honrado, J.; Gonalves, J. Combining Satellite Remote Sensing and Climate Data in Species Distribution Models to Improve the Conservation of Iberian White Oaks (Quercus L.). Int. J. Geo-Inf. 2020, 9 , 735. [CrossRef]

8. Leathwick, J.R. Incorporating the effects of inter-specific competition when modelling species distributions at landscape scales. Biodivers. Conserv. 2002, 11, 2177-2187. [CrossRef]

9. Lucas, F.; Abraham, E.G.; Isabelle, L.; Bernadette, J.; Gatan, L. A generic individual-based model can predict yield, nitrogen content, and species abundance in experimental grassland communities. J. Exp. Bot. 2018, 70, 2491-2504.

10. Pozsgai, G.; Baird, J.; Littlewood, N.; Pakeman, R. Phenological changes of the most commonly sampled ground beetle (Coleoptera: Carabidae) species in the UK environmental change network. Int. J. Biometeorol. 2018, 62, 1063-1074. [CrossRef]

11. Rainio, J.; Niemel, J. Ground beetles (Coleoptera: Carabidae) as bioindicators. Biodivers. Conserv. 2003, 12, 487-506. [CrossRef]

12. Massaloux, D.; Sarrazin, B.; Roume, A.; Tolon, V.; Wezel, A. Complementarity of grasslands and cereal fields ensures carabid regional diversity in French farmlands. Biodivers. Conserv. 2020, 29, 2861-2882. [CrossRef]

13. Szabolcs, L.; Eszter, D.; Tibor, M.; Bazartseren, B. Species Richness Responses to Structural or Compositional Habitat Diversity between and within Grassland Patches: A Multi-Taxon Approach. PLoS ONE 2016, 11, e0149662.

14. Sánchez-Bayo, F.; Wyckhuys, K.A.G. Worldwide decline of the entomofauna: A review of its drivers. Biol. Conserv. 2019, 232, 8-27. [CrossRef]

15. Eyre, M.D.; Lott, D.A.; Garside, A. Assessing the potential for environmental monitoring using ground beetles (Coleoptera: Carabidae) with riverside and Scottish data. Ann. Zool. Fenn. 1996, 33, 157-163.

16. Barber, N.A.; Lamagdeleine-Dent, K.A.; Willand, J.E.; Jones, H.P.; Mccravy, K.W. Species and functional trait re-assembly of ground beetle communities in restored grasslands. Biodivers. Conserv. 2017, 26, 3481-3498. [CrossRef]

17. Baselga, A. Determinants of species richness, endemism and turnover in European longhorn beetles. Ecography 2008, 31, 263-271. [CrossRef]

18. Eyre, M.; Rushton, S.; Telfer, M.G.L. Investigating the relationships between the distribution of British ground beetle species (Coleoptera, Carabidae) and temperature, precipitation and altitude. J. Biogeogr. 2010, 32, 973-983. [CrossRef]

19. Ribera, I.; Foster, G.N.; Vogler, A.P. Does habitat use explain large scale species richness patterns of aquatic beetles in Europe? Ecography 2003, 26, 145-152. [CrossRef]

20. Saska, P.; Martinkova, Z.; Honek, A. Temperature and rate of seed consumption by ground beetles (Carabidae). Biol. Control 2010, 52, 91-95. [CrossRef]

21. Tsafack, N.; Xie, Y.Z.; Wang, X.P.; Fattorini, S. Influence of Climate and Local Habitat Characteristics on Carabid Beetle Abundance and Diversity in Northern Chinese Steppes. Insects 2020, 11, 19. [CrossRef] [PubMed]

22. Marques, D.D.S.; Costa, P.G.; Souza, G.M.; Cardozo, J.G.; Barcarolli, I.F.; Bianchini, A. Selection of biochemical and physiological parameters in the croaker Micropogonias furnieri as biomarkers of chemical contamination in estuaries using a generalized additive model (GAM). Sci. Total Environ. 2019, 647, 1456-1467. [CrossRef]

23. Lu, Y.; Fu, B.; Wei, W.; Yu, X.; Sun, R. Major Ecosystems in China: Dynamics and Challenges for Sustainable Management. Environ. Manag. 2011, 48, 13-27. [CrossRef] [PubMed]

24. Lohr, C.A.; Hone, J.; Bode, M.; Dickman, C.R.; Wenger, A.; Pressey, R.L. Modeling dynamics of native and invasive species to guide prioritization of management actions. Ecosphere 2017, 8, e01822. [CrossRef]

25. Hang, J.; Shi, Y.; Liu, W.; He, D.H. Diversity of ground-dwelling beetles (Coleoptera) in restored habitats in the hill and gully area of Loess Plateau, Ningxia Hui Autonomous Region. Biodivers. Sci. 2014, 22, 516-526.

26. Tsafack, N.; Rebaudo, F.; Wang, H.; Nagy, D.; Xie, Y.Z.; Wang, X.P.; Fattorini, S. Carabid community structure in northern China grassland ecosystems: Effects of local habitat on species richness, species composition and functional diversity. PeerJ 2019, 6, e2197. [CrossRef]

27. Bai, L.; Ren, G.D. Diversity and Geographic Distribution of Beetles in Ningxia of China. Acta Agric. Boreali Sinica 2015, 24, 133-140.

28. Wei, S.H.; Huang, W.G.; Zhu, M.M.; Gao, L.Y.; Wang, Y.; Zhang, R.; Zhao, Z.H. The asymmetric responses of carabid beetles to steppe fragmentation in Northwest China. Glob. Ecol. Conserv. 2020, 23, e01058. [CrossRef] 
29. He, Q.; Wang, X.P.; Yang, G.J. Species diversity of carabid beetles in desert-steppe in Yanchi of Ningxia, China. Acta Ecol. Sinica 2011, 31, 923-932.

30. Liu, Y.; Yu, Z.; Wang, C.; Li, L.; Chang, H. The Diversity of Ground-dwelling Beetles at Cultivated Land and Restored Habitats on the Bashang Plateau. Acta Ecol. Sinica 2011, 31, 465-473.

31. Li, X.; Liu, Y.; Duan, M.; Yu, Z.; Axmacher, J. Different response patterns of epigaeic spiders and carabid beetles to varying environmental conditions in fields and semi-natural habitats of an intensively cultivated agricultural landscape. Agric. Ecosyst. Environ. 2018, 264, 54-62. [CrossRef]

32. Niemela, J. Carabid beetles (Coleoptera: Carabidae) and habitat fragmentation: A review. Eur. J. Entomol. 2001, 98, 127-132. [CrossRef]

33. Kromp, B. Carabid beetles in sustainable agriculture: A review on pest control efficacy, cultivation impacts and enhancement. Agric. Ecosyst. Environ. 1999, 174, 187-228. [CrossRef]

34. Wei, S.H.; Ma, L.J.; Bai, L.; Zhang, K.Y.; Zhang, R.; Gao, L.Y.; Wang, Y.; Zhu, M.M.; Huang, W.G. Preliminary Studies on Species Diversity of Beetles in Temperate Grassland and their Value as Bioindicators. J. Environ. Entomol. 2017, 39, $1287-1298$.

35. Benito, B.M.; Cayuela, L.; Albuquerque, F.S. The impact of modelling choices in the predictive performance of richness maps derived from species distribution models: Guidelines to build better diversity models. Methods Ecol Evol. 2013, 4, 327-335. [CrossRef]

36. Bertolino, S.; Sciandra, C.; Bosso, L.; Russo, D.; Lurz, P.W.W.; Di Febbraro, M. Spatially explicit models as tools for implementing effective management strategies for invasive alien mammals. Mamm. Rev. 2020, 50, 187-199. [CrossRef]

37. Cerrejón, C.; Valeria, O.; Mansuy, N.; Barbé, M.; Fenton, N.J. Predictive mapping of bryophyte richness patterns in boreal forests using species distribution models and remote sensing data. Ecol. Indic. 2020, 119, 106826. [CrossRef]

38. Guillera-Arroita, G.; Lahoz-Monfort, J.J.; Elith, J.; Gordon, A.; Kujala, H.; Lentini, P.E.; Mccarthy, M.A.; Tingley, R.; Wintle, B.A. Is my species distribution model fit for purpose? Matching data and models to applications. Glob. Ecol. Biogeogr. 2015, 24, 276-292. [CrossRef]

39. Mateo, R.G.; Felicisimo, A.M.; Munoz, J. Species distributions models: A synthetic revision. Rev. Chil. Hist. Nat. 2011, 84, 217-240. [CrossRef]

40. Lobo, J.M.; Lumaret, J.R.P. Modelling the species richness distribution for French AphodiN1ae (Coleoptera, ScarabaeoN1ea). Ecography 2010, 27, 145-156. [CrossRef]

41. Colwell, R.K.; Gotelli, N.J.; Ashton, L.A.; Beck, J.; Brehm, G.; Fayle, T.M.; Fiedler, K.; Forister, M.L.; Kessler, M.; Kitching, R.L. Midpoint attractors and species richness: Modelling the interaction between environmental drivers and geometric constraints. Ecol. Lett. 2016, 19, 1009-1022. [CrossRef]

42. Jiang, Y.; De Bie, C.A.J.M.; Wang, T.J.; Skidmore, A.K.; Liu, X.H.; Song, S.S.; Shao, X.M. Hyper-temporal remote sensing helps in relating epiphyllous liverworts and evergreen forests. J. Veg. Sci. 2013, 24, 214-226. [CrossRef]

43. Lehmann, A.; Overton, J.M.; Leathwick, J.R. GRASP: Generalized regression analysis and spatial prediction. Ecol. Model. 2002, 160, 165-183. [CrossRef]

44. Kang, L.; Han, X.; Zhang, Z.; Sun, O.J. Grassland ecosystems in China: Review of current knowledge and research advancement. Philos. Trans. R. Soc. B 2007, 362, 997-1008. [CrossRef] [PubMed]

45. Heikkinen, R.K.; Neuvonen, S. Species richness of vascular plantsin the subarctic landscape of northern Finland: Modelling relationships to the environment. Biodiver. Conserv. 1997, 6, 1181-1201. [CrossRef]

46. Bozdogan, T. Akaike's information criterionand recent developments in information complexity. J. Math. Psychol. 2000, 44, 62-91. [CrossRef] [PubMed]

47. Hastie, T.; Tibshirani, R. Generalized Additive Models; Chapman \& Hall/CRC: London, UK, 2006; p. 335.

48. Austin, M.P.; Meyers, J.A. Current approaches to modelling the environmental niche of eucalypts: Implication for management of forest biodiversity. Forest Ecol. Manag. 1996, 85, 95-106. [CrossRef]

49. Guisan, A.; Edwards, T.C.; Hastie, T. Generalized linear and generalized additive models in studies of species distributions: Setting the scene. Ecol. Model. 2002, 157, 89-100. [CrossRef]

50. Kosicki, J.Z. Generalised Additive Models and Random Forest Approach as effective methods for predictive species density and functional species richness. Environ. Ecol. Stat. 2020, 27, 273-292. [CrossRef]

51. Carrasco, L.; Mashiko, M.; Toquenaga, Y. Application of random forest algorithm for studying habitat selection of colonial herons and egrets in human-influenced landscapes. Ecol. Res. 2014, 29, 483-491. [CrossRef]

52. Vorpah, P.; Elsenbeer, H.; Märker, M.; Schröder, B. How can statistical models help to determine driving factors of landslides? Ecol. Model. 2012, 239, 27-39. [CrossRef]

53. Burnhan, K.P.; Anderson, D.R. Model selection and multi-model inference: A practical Information-theoretic approach. Technometrics 2002, 45, 181.

54. Potts, S.E.; Rose, K.A. Evaluation of GLM and GAM for estimating population indices from fishery independent surveys. Fish Res. 2018, 208, 167-178. [CrossRef]

55. Chiang, A.Y. Generalized Additive Models: An Introduction with R. Technometrics 2012, 49, 360-361. [CrossRef]

56. Lobo, J.M.; Lumaret, J.P.; Jay-Robert, P. Modelling the Species Richness Distribution of French Dung Beetles (Coleoptera, Scarabaeidae) and Delimiting the Predictive Capacity of Different Groups of Explanatory Variables. Global Ecol. Biogeogr. 2002, $11,265-277$. 
57. Kotze, D.J.; Brandmayr, P.; Casale, A.; Emmanuelle, D.R.; Dekoninck, W.; Koivula, M.J.; Lövei, G.L.; Mossakowski, D.; Noordijk, J.; Paarmann, W.; et al. Forty years of carabid beetle research in Europe-From taxonomy, biology, ecology and population studies to bioindication, habitat assessment and conservation. ZooKeys 2011, 100, 55-148. [CrossRef] [PubMed]

58. Kosicki, J.Z. Should topographic metrics be considered when predicting species density of birds on a large geographical scale? A case of Random Forest approach. Ecol. Model. 2017, 349, 76-85. [CrossRef]

59. Magura, T.; Elek, B.T. Diversity and composition of carabids during a forestry cycle. Biodiver. Conserv. 2003, 12, 73-85. [CrossRef]

60. Yang, Y.; Dou, Y.; An, S. Environmental driving factors affecting plant biomass in natural grassland in the Loess Plateau, China. Ecol. Indic. 2017, 82, 250-259. [CrossRef]

61. Niemela, J.; Haila, Y.; Halme, E.; Pajunen, T.; Puntilla, P. Small scale heterogeneity in the spatial distribution of carabid beetles in the southern Finnish taiga. J. Biogeogr. 1992, 19, 173-181. [CrossRef]

62. Yang, G.J.; Wang, M.; Yang, Y.; Li, X.; Wang, X.P. Distribution patterns and environmental interpretation of beetle species richness in Helan Mountain of northern China. Biodiver. Sci. 2019, 27, 1309-1319.

63. Wang, Y.; Shi, X.; Yang, G.J.; Jia, L. Beetle species diversity distribution patterns and its environmental associations in Ningxia in Northwest China. Chin. J. Ecol. 2020, 39, 3738-3747.

64. Fattorini, S. Beetle Species-Area Relationships and Extinction Rates in Protected Areas. Insects 2020, 11, 646. [CrossRef]

65. Uzman, D.; Entling, M.H.; Leyer, I.; Reineke, A. Mutual and Opposing Responses of Carabid Beetles and Predatory Wasps to Local and Landscape Factors in Vineyards. Insects 2020, 11, 746. [CrossRef]

66. Tong, Y.J.; Yang, H.D.; Jenkins Shaw, J.; Yang, X.K.; Bai, M. The Relationship between Genus/Species Richness and Morphological Diversity among Subfamilies of Jewel Beetles. Insects 2021, 12, 24. [CrossRef]

67. Thacker, J.R.M. Carabidologists and fragmented habitats. Trends Ecol. Evol. 1996, 11, 103-104. [CrossRef]

68. Pineda, E.; Lobo, J.M. Assessing the accuracy of species distribution models to predict amphibian species richness patterns. J. Anim. Ecol. 2009, 78, 182-190. [CrossRef]

69. Fung, T.; Verma, S.; Chisholm, R. Probability distributions of extinction times, species richness, and immigration and extinction rates in neutral ecological models. J. Theor. Biol. 2020, 485, 110051. [CrossRef] [PubMed] 